\section{Advice and consent}

The UK government last week published a White Paper (Cmnd. 6820) in response to the Flowers Commission report on nuclear power and the environment. Chris Sherwell reports

THE bare bones of the UK government's 17-page response to the Flowers report give those involved in Britain's nuclear debate something to chew over, but many will wonder whether it was worth the eight-month wait. The White Paper says the government has decided to accept the bulk of the Flowers Commission's recommendations. The most concrete action proposed concerns management of radioactive waste. The government also plans to broaden the range of advice it receives, and wants more information made available to the public to facilitate full discussion.

It is only at the end of the White Paper and in the context of public discussion that one of the hard foci of Britain's nuclear debate, the demonstration commercial fast breeder reactor (CFR1), actually surfaces. The government accepts, says the White Paper, that before any decision is taken on CFR1, a special procedure for achieving a proper framework for wider public debate should be settled and announced. Presenting the White Paper last week, the Environment Secretary, Mr Peter Shore, confirmed that CFR1 would not proceed until there had been a broad-ranging examination and debate. He cited the machinery of the Public Inquiry Commission which was available but had not been used as one possible course.

In accordance with the Flowers Commission's recommendation responsibility for the management of radioactive waste has now been given to the Environment Secretary together with the heads of the Scottish and Welsh offices. The government has also accepted in principle Flowers' suggestion for a Nuclear Waste Management Advisory Committee, though it thinks that initially this need not be a statutory body. It also sees no need for a decision yet on the suggestion for a Nuclear Waste Disposal Corporation, but says it will reconsider this in light of a review of existing arrangements for the control of waste which the government is now, according to the White Paper, carrying out "as a priority task".

On both waste management and radiation standards the White Paper announces important changes affecting the control of research. The Secretaries of State for the Environment, Scotland and Wales will "assume control of the waste management element" in the UKAEA's total R\&D expenditure. And responsibility for initiating and coordinating research into the effects of radioactivity on man and the environment can, says the White Paper, "be more appropriately performed by a Minister than (as the Commission suggested) by the National Radiological Protection Board (NRPB)'”.

$\mathrm{Mr}$ Shore amplified on this reasoning last week only to say both research and policy were in the public domain. Responsibility would again be exercised by the three ministers acting jointly. So will "strategic responsibility" for monitoring environmental pathways lie with the ministers rather than with the NRPB. The government does accept the Commission's recommendation that the NRPB should have a statutory responsibility for advice on the adequacy of radiation standards for workers and the general public. The membership of the NRPB and its sources of finance are now being reviewed.

On nuclear safety generally the advice the government now receives from the Nuclear Installations Inspectorate, which is part of the Health and Safety Executive, will be supplemented by advice from another independent and expert source. This will be the Advisory

\section{Lords judgment}

EUROPEAN policies are never easily come by, least of all in energy. With the next chance for the Nine to take a step towards a common policy coming on 14 June, when the EEC Council of Energy ministers meets, more worried voices have added a note to the chorus of concern that normally prevails.

It comes from the House of Lords, whose Select Committee on the European Communities is one body in Britain that seeks actually to dissect the stream of proposals and consultative documents emanating from Brussels. Last week the committee released the latest example of its valuable work-its 28 th report-to coincide with a debate in the House.

Coming from sub-committtee $F$, which deals with energy, transport and research, the report examines three energy documents prepared by the Commission for the Council of Ministers. One compared EEC objectives set in 1974 with member states' forecasts of their own production and demands; the second warned of the lack of progress towards the aim of greater self-sufficiency; the third focused on the coal industry.
Committee on the Safety of Nuclear Installations, which is being set up in place of the former Nuclear Safety Advisory Committee to advise the Health and Safety Commission.

The pieces of this institutional jigsaw will be increased further by the creation ("pretty soon", according to Mr Shore) of what the White Paper calls a high-level independent body "to advise specifically on the interaction between energy policy and the environment". And there is still Mr Benn's Energy Commission to come.

The White Paper emphasises that a decision both on the choice of thermal reactor (which a junior minister at the Energy Department, Dr John Cunningham, last week said was "imminent") and on the further development of the breeder, would not of themselves involve any commitment to a large additional nuclear programme. "Much more significant" decisions will be needed in a few years' time, it says. A Green Paper on energy policy later this year is expected to spell this out in greater detail.

An air of caution is further conveyed early on in the White Paper. International discussions on nuclear policy, it says, mean that the government is "not yet in a position to give a final response" to certain conclusions and recommendation from Flowers on the two "central issues" of waste and security. That more than anything else confirmed that in nuclear power politics, almost nothing is final.

The committee's criticism is almost unsparing No reliable conclusion can be drawn from the Commission's statistics, its says. There are unexplained inconsistencies and omissions in the figures. Important assumptions are insufficiently discussed, let alone justified. And the figures are not clear and persuasive enough to encourage the Council to take any important decisions, and could even provide an excuse for inaction.

The committee considers that the Community's attention should be concentrated "less on objectives and forecasts and more on the successes and failures of national policies, on the reasons for them, and on research into means of improvement, both technological and social".

One problem may be a surfeit of analysis and of discussion. As Lord Sherfield, a former head of the UK Atomic Energy Authority, commented in debate last week: "While the clock ticks it is difficult to find much that is new to say about the problem until something is actually done about it".

Chris Sherwell 